\title{
Maladaptive Perfectionism and Academic Achievement in Indonesian Gifted Undergraduate Students: Goal Adjustment as Moderator
}

\author{
Fitriani Yustikasari Lubis ${ }^{1}$, Lydia Freyani Hawadi ${ }^{2}$, Rose Mini Agoes Salim ${ }^{3}$, R. Urip Purwono ${ }^{4}$ \\ ${ }^{1,2,3}$ Fakultas Psikologi, Universitas Indonesia, Depok, Indonesia \\ ${ }^{1,4}$ Fakultas Psikologi, Universitas Padjadjaran, Sumedang, Indonesia \\ e-mail: fitriani.yustikasari@ui.ac.id
}

\begin{abstract}
This paper examines the role of goal adjustment (goal disengagement and goal re-engagement) as a moderator of maladaptive perfectionism and academic achievement in Indonesian gifted undergraduate students. This cross-sectional study employs a mixed-method sequential explanatory approach. On the quantitative stage, eighty-six undergraduates identified as gifted students completed Frost Multidimensional Perfectionism Scale, Goal Adjustment Scale and selfreported GPA. On the qualitative stage, eight participants were selected from the quantitative stage to participate in a face to face interview. The result showed that maladaptive perfectionism negatively correlated with academic achievement. The interaction between maladaptive perfectionism and academic achievement moderated by goal disengagement show significant interaction, while goal re-engagement was not significant.
\end{abstract}

Keywords: maladaptive perfectionism, academic achievement, goal disengagement, goal reengagement, gifted undergraduate students

\begin{abstract}
Abstrak
Tujuan penelitian ini menjelaskan peran goal adjustment (goal disengagement and goal reengagement) sebagai moderator dari perfeksionisme maladaptif dan prestasi akademik pada mahasiswa berbakat intelektual Indonesia. Rancangan penelitian menggunakan metode penelitian campuran sekuensial. Pada tahap kuantitatif, delapan puluh enam mahasiswa yang diidentifikasi sebagai mahasiswa berbakat intelektual melengkapi Frost Multidimensional Perfectionism Scale, Goal Adjustment Scale dan melaporkan nilai IPK. Pada tahap kualitatif, dipilih delapan peserta dari tahap kuantitatif untuk mengikuti wawancara tatap muka. Hasil penelitian menunjukkan bahwa perfeksionisme maladaptif berkorelasi negatif dengan prestasi akademik. Interaksi antara perfeksionisme maladaptif dan prestasi akademik dimoderatori oleh goal disengagement menunjukkan interaksi yang signifikan, sedangkan interaksi moderator goal re-engagement tidak terbukti signifikan.
\end{abstract}

Kata Kunci: perfeksionisme maladaptif, prestasi akademik, goal disengagement, goal reengagement, mahasiswa berbakat intelektual

\section{Introduction}

Academic achievement in undergraduate study is one of the crucial topics because it is an indicator of success in studying in higher education. Gifted undergraduate students are assumed to always succeed in achieving high academic achievements (Sousa, 2009). Not all gifted undergraduate students can achieve high academic achievements (Blaas, 2014; Davis et al., 2014; Neihart et al., 2002; Rimm, 2006). The factor that contributed to academic achievement involved cognitive and non-cognitive (Moreno, 2010). Steiner and Carr (2003) explained that gifted students have better metacognition compared to students in general. They have a broader knowledge base, like complex situations, and are more challenging, faster, and rich in strategies for solving problems. Therefore, in terms of cognition, gifted students have no difficulty in achieving high academic achievement. Non-cognitive factors that are believed to be obstacles to achieving in academics for gifted students 
(Neihart et al., 2002; Rimm, 2006; VanTassel-Baska et al., 2009).

Non-cognitive factors, especially social-emotional, are a challenge experienced by many gifted undergraduate students. Based on research literature, many social-emotional problems are caused by perfectionist characters, although there is also other characteristics such as asynchronous development or high sensitivity (Hébert \& Smith, 2018; Kakavand et al., 2017; Mofield \& Peters, 2015; Neihart et al., 2002; Orange, 1997; Parker, 2000; Peterson et al., 2009; Silverman, 1999; Speirs Neumeister, 2004a). As mention above, perfectionism is believed to be one of the non-cognitive factors that cause a lack of academic achievement (Fong \& Yuen, 2014; Rimm, 2006). Perfectionism has long been regarded as a personality trait on characteristics of gifted learners (Fong \& Yuen, 2014; Miller et al., 2012; Mofield \& Peters, 2015; Sastre-Riba et al., 2019; Speirs Neumeister, 2004b; Speirs Neumeister \& Finch, 2006; Stornelli et al., 2009; Wang et al., 2012). Approximately $75 \%$ to $87.5 \%$ of gifted students are perfectionists (Chan, 2010; Davis et al., 2014).

Multidimensional perfectionism was for the first time proposed by Hamachek in 1978, who differentiated between "normal" versus " neurotic" perfectionism. Based on his conception, later researchers have investigated perfectionism using a multidimensional perspective, including Frost et al. (1991). Frost et al. (1990) view perfectionism "as involving high standards of performances which are accompanied by tendencies for overly critical evaluations of one's behavior" (p. 450). If this high personal standard is accompanied by excessive concern over mistakes and always doubting the adequacy of one's action, the perfectionist behavior could be associated with dysfunctional outcomes. On the other hand, a high personal standard with a good organization would lead to adaptive outcomes that might need by gifted undergraduate students to achieve excellence (Kerr, 2009).

Perfectionism has been established as a multidimensional construct with adaptive and maladaptive aspects that relate differently to success in the academic context (Blankstein et al., 2008; Brown \& Heimberg, 1999; Elion et al., 2012; Grzegorek et al., 2004). A qualitative study on gifted undergraduate students found that those with maladaptive perfectionism learned with a motive to avoid failure and tended to procrastinate in their work. In contrast, those with adaptive perfectionists learn with a motive to achieve mastery. Therefore, they developed a strong work ethic and were motivated to seek out challenges (Speirs Neumeister, 2004b). There were only a few perfectionism studies that focused on Asian gifted undergraduate students, let alone gifted undergraduate students in Indonesia (Chan, 2010; Fong \& Yuen, 2014; Lee \& Park, 2011; Lubis et al., 2020). It is assumed that perfectionism harms gifted undergraduate students such as depression and procrastination if we refer to other perfectionism research on high school students in Indonesia (Ananda \& Mastuti, 2013; Nurhayati et al., 2014; Rosadi \& Widayat, 2012). Therefore, it is needed to explore more about perfectionism in Indonesian gifted undergraduate students. We define these "gifted undergraduate students" in our study as "students who possess potential abilities that give evidence of exceptionally high ability pertaining intellect, creativity, and task commitment," of which definition uses Renzulli's notion of 'The Three Rings Conception'(Renzulli \& Reis, 1985).

This study explores the factor needed by the gifted undergraduate students to buffer the negative effect of perfectionism on academic achievement from a cognition perspective. The gifted undergraduate students have an ideal schema that high standards in their academic goals must be 
obtained at any cost (Speirs Neumeister, 2004a). Therefore, they fear to make mistakes or engage in activities that might prevent them from achieving a high academic goal. With their ability, the gifted undergraduate students believe they could achieve the highest goal available in an academic setting without considering other aspects such as fatigue in learning, dynamics in learning in a team, or other students' abilities. This belief, in certain situations, leads to unattainable high goals that, in the end, could contribute to their difficulties in meeting their academic goals.

Some previous studies related to perfectionism and academic achievement findings still showed different results. Studies showed a significant relationship between perfectionism and academic achievement (Blankstein et al., 2008; Brown \& Heimberg, 1999; Elion et al., 2012; Grzegorek et al., 2004) while other studies showed no significant relationship (Brumbaugh et al., 2007; Rice \& Dellwo, 2002). Studies showed a significant relationship argued that personal standard dimension positively correlated with students' midterm and final exam result, but dimension concern over a mistake from Frost Multidimensional Perfectionism Scale (FMPS) is not associated with good grades (Brown \& Heimberg, 1999). Elion et al. (2012) and Grzegorek et al. (2004) explain that a perfectionist student has a higher Grade Point Average (GPA) than a non-perfectionist student. Studies that show no significant relationship between perfectionism and GPA argue that there was no difference in results between perfectionist and non-perfectionist (Rice \& Dellwo, 2002). Another study assumed no significant relationship, which is possibly related to the influence of personality factors, and individual differences believed to be mediated mainly by how individuals cope with stressful situations (Brumbaugh et al., 2007). Due to inconsistencies, this study aims to discover the moderator variable that will be differentiated the relationship between maladaptive perfectionism and academic achievement.

Prolonged confrontation with unattainable academic goals, combined with their perfectionist mindset, could enhance psychological distress in students; they need to regulate these adverse effects (O'Connor \& Forgan, 2007). Wrosch et al. (2003) have argued that a person can regulate that negative effect adaptively. This capacity is goal adjustment that consists of the capacity to disengage the unattainable goals and re-engage with new attainable goals (Wrosch et al., 2003). Goal adjustment could play the role of moderator to minimize the negative effect of perfectionism on academic achievement. The present study combines the research of perfectionism, academic achievement, and goal adjustment.

Goal adjustment is assumed to be a factor that could buffer the negative effect of maladaptive perfectionism and differentiated its effect on academic achievement. In the effort to complete their academic life, gifted undergraduate students often develop high personal standards. Related to their high intellectual ability, the gifted undergraduate students set their academic standards in excellent grades or a GPA of 4.00. Based on the gifted undergraduate students' experiences during elementary until high school, this academic achievement seems attainable for them to achieve. Some of the gifted undergraduate students even define themselves based on their excellent academic achievement. However, when gifted undergraduate students entered university with a more competitive and complex education atmosphere and more excellent students like them, some of the gifted undergraduate students failed to get good grades as their goal expectation. GPA of 4.00 becomes an unattainable goal due to many factors despite their high intellectual ability.

Wrosch et al. (2003) say that an individual could modify goals based on 
perceived attainability, referred to as goal adjustment ability. Two independent sets of skills are purported to contribute to goal adjustment ability: goal disengagement and goal re-engagement (Wrosch et al., 2003). Goal disengagement (GD) is the ability to evaluate the demands of a given goal and cognitively and behaviorally "let-go" when goals are perceived as unattainable. Goal re-engagement (GR) is the ability to shift attention toward generating and reengaging in more achievable goals (Wrosch et al., 2003).

The previous study about goal adjustment in relationship with perfectionism found that there is an impact on depression. Interaction between perfectionism and GD predicts stressrelated depression and maladaptive coping. In contrast, perfectionism interacts with GR predict more adaptive coping (Eddington, 2014). While the previous study about goal adjustment and academic achievement shows no significant association between goal adjustment ability and ability to solved a given task. Both GD and GR show no differences in time in finishing tasks. However, GR predicts persistent behavior when dealing with unsolvable tasks. GD is associated with a higher baseline of heart rate when facing unsolvable tasks (Messay \& Marsland, 2015).

Being able to cope with failure means gifted undergraduate students need to be flexible in setting their academic standards. However, perfectionist gifted undergraduate students tend to be rigid in setting too high personal standards (Callard-Szulgit, 2012; Kerr, 2009). When in the process, this overly high personal standard is unattainable, it is quite difficult for them to adjust. Here, the concept 'Goal Adjustment' is relevant, implying that someone can disengage and reengage from their meaningful yet unattainable goals (Wrosch et al., 2003). When gifted undergraduate students can make goal adjustments, they tend to be more persistent in solving their academic tasks, and therefore they are assumed to be more able to achieve (Messay \& Marsland, 2015).

The mixed-method is a powerful approach to provide a more comprehensive explanation of a phenomenon (Creswell, 2016). Also similar studies on gifted subjects in Indonesia that have been done previously still rarely use this method. Therefore, we hypothesize there are changes in the relationship between maladaptive perfectionism and academic achievement for gifted undergraduate students with goal adjustment as moderators. It is followed by the qualitative stage to explain how perfectionism and goal adjustment impact academic achievement in Indonesian gifted undergraduate students.

\section{Methods}

This study conducted a cross-sectional study using a sequential explanatory model. This model consisted of two-stage, first collecting quantitative data and then gather qualitative data to help deepen the finding in the quantitative stage (Creswell \& Creswell, 2018).

The current study obtained ethics approval from the Ethics Committee in the Faculty of Psychology, University of Indonesia No.316/F.Psi.KomiteEtik/ PDP.04.00/2017.

\section{Quantitative Stage \\ Sample Size and Sampling Methods}

Purposive sampling was used as the sampling method. The participants' characteristics were: (1) registered in the undergraduate program in one of the three elected universities and (2) gifted according to the Three Rings Renzulli concept of giftedness (above average ability score IQ $\geq 125$, high levels of task commitment score $\mathrm{TC} \geq 130$, and high levels of creativity score CQ $\geq 110$ ) (Renzulli \& Reis, 1985). To meet those criteria, we selected potential participants using two stages of selection and screening from three of the top-fourteen universities in Indonesia 
based on Indonesia Ministry of Education and Culture ratings (Siaran Pers Kemenristekdikti, 2017); In the selection phase, they were nominated by their faculty or nominating themselves with criterion alumni of the gifted school program (acceleration class) or IQ above 130. Two hundred and twelve students were selected in the selection phase. The process proceeded with the screening phase, they were compulsory to take a psychological assessment, i.g. intelligence test (Tes Intelegensi Kolektif Indonesia-Tinggi/ TIKI-T) (Drenth et al., 1976), creativity test (Tes Kreativitas Verbal/ TKV) (Munandar, 2011), and task commitment test (Task Commitment-Rendi/ TC-Rendi) (Hawadi dalam Akbar-Hawadi, 2004). Those that meet the Three Rings Renzulli conception of giftedness: IQ score above 125, CQ (creativity quotient) above 110, and TC score above 130 are included as participants. A total of 86 undergraduate gifted students meet the criteria of the screening phase.

\section{Measures}

Three instruments were used. We translated both the brief scale of Frost Multidimensional Perfectionism Scale (FMPS) (Frost et al., 1990) and The Goal Adjustment Scale (GAS) (Wrosch et al., 2003) from English into Indonesia language using forward and backtranslation techniques. The forward translation was conducted independently by two English-Indonesian translators whose first language was Indonesia. Back translation was conducted by two Indonesian scholars with a TOEFL score of a minimum of 600 . After several rounds of comparing, contrasting, and combining the translations, we conducted cognitive interviews with undergraduate students and finalized the Indonesian versions of the brief scale of FMPS and GAS.

The first instrument, the brief scales of Frost Multidimensional Perfectionism Scale (FMPS) (Frost et al, 1990). We measured maladaptive perfectionism using three subscales the Personal Standards (PS) 7 items; e.g. "I set higher goals for myself than most people", the Concern over Mistakes (CM) 9 items; e.g. "If I fail at work/ school, I am a failure as a person", and the Doubt about Action (DA) 4 items; e.g. "I tend to get behind in my work because I repeat things over and over" (Stoeber, 2018). Participants responded to all items using a five-point Likert scale (from 1- "strongly disagree" to 5- "strongly agree"). The total score ranges from 20 to 100, with higher scores indicating higher levels of perfectionism, viewed as a maladaptive trait (Frost et al., 1990). The original version was adapted to Indonesian. Cronbach's alpha was used to calculate internal consistency, PS Cronbach's $=.81$; CM Cronbach's $=.85$; DA Cronbach's $=$ .58 (Field, 2009). Confirmatory factor analysis (CFA) was used to evaluate the construct validity. The results showed satisfactory construct validity, Chi-Square $\mathrm{p}$-value $=.406$, root means square error of measurement (RMSEA) $=.01$ and comparative fit index $(\mathrm{CFI})=.99$.

Second, The Goal Adjustment Scale (GAS) (Wrosch et al., 2003). The GAS included four items that measured goal disengagement (GD); e.g." It's easy for me to reduce my effort towards the goal" and six items measuring goal re-engagement (GR); e.g "I convince myself if that I have other meaningful goals to pursue". The scale consists of 10 five-point Likert items (from 1- "strongly disagree" to 5-"strongly agree"), with higher scores indicating better ability to disengage from goals (GD) or to re-engage in alternative goals (GR) in the face of failure. The original version had a Cronbach's alpha of .84 for GD and .86 for GR (Wrosch et al., 2003). The Indonesian version had a Cronbach's alpha of .71 and .83 for the GD and GR, respectively.

Finally, The cumulative Grade Point Average (GPA) of each participant functioned as a measurement for academic achievement. Undergraduate gifted undergraduate students were asked to self- 
reporting their current GPA. Based on a 4point scale, GPA can range from 0 to 4.00 (Peraturan Menteri Pendidikan dan Kebudayaan Republik Indonesia Nomor 3 Tahun 2020 tentang Standar Nasional Pendidikan Tinggi pasal 27, 2020). In the study, the range of GPA obtained from respondents was 2.66 to 4.00 , with a mean of 3.41 and a standard deviation of .34 . The GPA distribution was skewed, a change of extreme score with mean score plus two SD was used to normalize the distribution (Field, 2009).

\section{Data Analysis}

Descriptive statistics scales, means, and standard deviations (SD) were calculated for continuous data. The Pearson bivariate correlation analysis was calculated to check the correlation between maladaptive perfectionism, dimensions of goal adjustment, and academic achievement. A moderation analysis was conducted to test the moderation effects of goal adjustment utilized the PROCESS Moderation Model 2 (Hayes, 2018). Maladaptive perfectionism as an independent variable, goal disengagement, and goal re-engagement as a moderator variable, and academic achievement as a dependent variable.

\section{Qualitative Stage}

Sampling Methods

Eight participants were selected from the participants in the quantitative stage based on scores for perfectionism and academic achievement (Creswell \& Creswell, 2018). It consists of mixed four participants with high perfectionism score and a low GPA and four participants with a low perfectionism score and a high GPA

\section{Data Collection}

The qualitative data were collected through 60-90 minutes interviews using a semi-structured interview technique. The participants were interviewed about their experiences and thought related to perfectionism's impact on academic achievement and the role of goal adjustment. Sample interview questions included the following: "In your opinion, how does perfectionism play a role in your academic achievement?" "If there are obstacles to achieving targeted academic achievement, how do you manage your high standards?". The interview was conducted individually with 2-3 sessions, depending on the information received during the interview. All interviews were audiotaped and transcribed verbatim in a word document.

\section{Data Analysis}

The qualitative content analysis emphasizes interpretation, subjectivity, flexibility in the process, and concern for the influence of context on the research process (Creswell, 2007). The data was recorded using a recorder or recording application on a smartphone. Recorded data was transcripted, then analyzed using thematic analysis, in which themes and categories were explored to reveal the goal adjustment role in perfectionism and academic achievement.

\section{Results and Discussion}

\section{Quantitative Result}

A total of 86 gifted undergraduate students, as shown in table 1 , with more female participants than male participants. The age range consists of 17-22 (mean age 19.77, SD = 1.43). The means, standard deviations, and correlation for each variable examined are displayed in table 1. The mean GPA score of 3.41 suggests that the academic achievement of undergraduate gifted undergraduate students was high (Peraturan Menteri Pendidikan dan Kebudayaan Republik Indonesia Nomor 3 Tahun 2020 tentang Standar Nasional Pendidikan Tinggi pasal 27). It can be seen that GPA correlated significantly with FMPS and GD, but not with GR. 
Maladaptive Perfectionism and Academic Achievement in Indonesian Gifted Undergraduate Students: Goal Adjustment as Moderator (Fitriani Yustikasari Lubis, Lydia Freyani Hawadi, Rose Mini Agoes Salim, R. Urip Purwono)

Table 1

Descriptive Statistics and Correlation between Perfectionism, Dimensions of Goal Adjustment, and Academic Achievement

\begin{tabular}{lcccccc}
\hline Subscale & M & SD & FMPS & GD & GR & GPA \\
\hline FMPS & 66.47 & 11.58 & - & & & \\
(PS, & & & & & & \\
CM, & & & & & & \\
DA) & & & & & & \\
GAS & & & & & & \\
$\quad$ GD & 10.60 & 2.96 & -.133 & - & & \\
GR & 23.40 & 3.76 & .068 & .42 & & \\
& & & & & \\
GPA & 3.41 & .40 & - & .25 & .142 & - \\
& & & $.207^{*}$ & $6^{* *}$ & & \\
\hline
\end{tabular}

*. Significant at the 1 level (2-tailed).

**. Significant at the 05 level (2-tailed).

Notes: the following abbreviation were used: FMPS

(Frost Multidimensional Perfectionism Scale), GAS

(Goal Adjustment Scale), GD (Goal Disengagement), GR (Goal Re-engagement), and Grade Point Average (GPA).

A simple linear regression was calculated to predict academic achievement based on perfectionism. A significant regression equation was found $(F(1.84)=$ $3.744, \mathrm{p}<0.1)$, with an R2 of .043 . Participants' predicted academic achievement is equal to $3.409-.083$ perfectionism level. Table 2 shows the calculation for moderation in predicting goal adjustment: GD and GR with perfectionism and academic achievement. In the analysis of goal disengagement, the main effect reveals that perfectionism does not predict academic achievement $\mathrm{B}=-.07$ $95 \% \mathrm{CI}=\left[\begin{array}{ll}-.15, & .02\end{array}\right]$ and goal disengagement significantly predict academic achievement $\mathrm{B}=.0895 \% \mathrm{CI}=[.05$, .16].

The interaction between perfectionism and academic achievement moderated by goal disengagement shows significant interaction $\mathrm{B}=-.106195 \%$ CI [-.1416, .0106]. We further unpacked the interaction by looking at the effects of perfectionism on academic achievement on different goaldisengagement conditions. If the participant has a high level of goal disengagement, the participants' perfectionism was negatively associated with academic achievement, $\mathrm{B}=$ $-.144495 \% \mathrm{CI}=[-.2503,-.0384]$.

If the participant has a low level of goal disengagement, the participants' perfectionism was positively associated with academic achievement. However, this effect was nonsignificant, $\mathrm{B}=.006295 \% \mathrm{CI}$ $=[-.0101, .1142]$.

In the analysis of goal re-engagement, the main effect shows that perfectionism significantly predicts academic achievement, $\mathrm{B}=-.1095 \% \mathrm{CI}=[-.19,-.01]$ and goal re-engagement does not predict academic achievement, $\mathrm{B}=.08$ 95\% $\mathrm{CI}=[-$ $.01, .16]$. The interaction between perfectionism and academic achievement moderated by goal re-engagement was nonsignificant, $\mathrm{B}=-.014195 \% \mathrm{CI}[-.0770$, .0468]. The interaction means that included goal re-engagement, only perfectionism had a negative effect on academic achievement, and goal re-engagement

Table 2

Regression PROCESS Output of Moderation Analysis and Conditional Effects (Goal Disengagement (GD) and Goal Re-engagement (GR) with Perfectionism (FMPS) and Academic Achievement (GPA))

\begin{tabular}{|c|c|c|c|c|c|c|c|c|}
\hline Factor & Model & $\begin{array}{l}\text { Int } \\
\text { Sig. } C I)\end{array}$ & $\begin{array}{l}\text { Low } \\
\text { Effect }\end{array}$ & Sig. $(C I)$ & $\begin{array}{l}\text { Med } \\
\text { Effect }\end{array}$ & Sig. $(C I)$ & $\begin{array}{l}\text { High } \\
\text { Effect }\end{array}$ & Sig. $(C I)$ \\
\hline $\begin{array}{l}\text { FMPS - } \\
\text { GPA } \\
\text { GD }\end{array}$ & -.1061 & $\begin{array}{l}-.1416,- \\
.0106\end{array}$ & .0062 & $-.0101, .1142$ & -.1691 & $\begin{array}{l}-.1516,- \\
.0135\end{array}$ & -.1444 & $\begin{array}{l}-.2503, \\
-.0384\end{array}$ \\
\hline $\begin{array}{l}\text { FMPS- } \\
\text { GPA } \\
\text { GR }\end{array}$ & .0141 & $-.0770, .0468$ & & & & & & \\
\hline
\end{tabular}

Note. Table reconstructed from SPSS PROCESS outputs for Perfectionism and Academic Achievement. Values for quantitative moderators are the mean and plus/minus one SD from the mean. Level of confidence for all confidence intervals in output: 95,0000 . 
showed no main effect nor interaction with perfectionism.

\section{Qualitative Result}

The eight gifted undergraduate students who are selected from the quantitative stage, four females and four males aged range 19-21 years old. Four gifted undergraduate students were selected from the high level of maladaptive perfectionism - low GPA (male: 3, female: 1). Four students were selected from the low level of maladaptive perfectionism high GPA (male: 1, female: 3 ).

Two main categories were extracted from the interview: perfectionism contribution to academic achievement and goal adjustment role in the relationship between perfectionism and academic achievement.

\section{Theme 1: Perfectionism Contribution to Academic Achievement}

The high level of maladaptive perfectionism - low GPA see themselves as a perfectionist, while the low level of maladaptive perfectionism - high GPA think themselves as non-perfectionist. Even if they were perfectionists, now they perceive themselves as non-perfectionist. Both groups agree that perfectionism harms their academic achievement in university. "In high school and the first semester, I am academic-oriented and perfectionist. For example, if I aim to get 100 in my assignment, then I have to get that 100. However, as time goes by, now, I no longer insisted on that score. I am aware of my efforts, and the grade is suited to my effort... I am satisfied with the good academic grades I get." (F, 19 yo)

They believe in their perfectionism, making it difficult for them to accept their limitations. It causes them to have difficulty in compromise their high standards of academic achievement. These high standards lead them to behave in a counterproductive manner, for example, focusing more on the process of making and preparing tasks rather than completion, difficulty sleeping, or thinking negatively about their academic assignments and tasks. "When making a practicum report, for example, I imagine that the report would not be anything good. Thus, right in the middle of working on the report, I suddenly do not have any idea, like I already feel 'ah', this will not be good. I will start all over again with a different point of view. Usually, in the end, I do not have time for the conclusion. So I just do it carelessly, and it reduces the score. "(F, 19 yo)

The low level of maladaptive perfectionism - high GPA group said when they could accept their limitations. They are better able to direct themselves more productively toward academic achievement activities. "...Because everyone in my school is so smart, at first, I felt like I could not be the first rank again. Then at that time, my motivation for learning dropped because of that thought...Then my parent made realized that I should not push myself too hard and accept that not all is according to my standard...Then finally, from there, I started to study again and started to get good grades. "(F, 19 yo)

\section{Theme 2: Goal Adjustment Role in the Relationship between Perfectionism and Academic Achievement}

Both groups agreed that as gifted undergraduate students, they only had one meaningful goal as their standard. In academic matters, this meaningful goal is to get the highest academic achievement. However, the difference is still seen in the two groups. When the low level of maladaptive perfectionism - high GPA group has difficulty achieving their goals, they can disengagement with their goal, even though it is only temporary. They said this happens because they realize that they have limitations either because of something in themselves that they missed to predict or something from external factors, so they understand the necessity to make new goals as a bridge to achieving their meaningful main goal. The high level 
of maladaptive perfectionism - low GPA could not disengage with their meaningful goal, even for temporary.

"Because I want to be realistic, for example, I will evaluate if this could be achieved or not. So at least if that is not achieved, I will not fall too far. I will be able to recover again and look at the future again. I have immediately proceeded to the next plan. I have never changed the main plan to success in my majoring, but for now, I take a different road for a while." (F, 21 yo)

As for the goal re-engagement process, this is not happening in gifted undergraduate students. Even if they say they are setting a new goal, this goal is not as meaningful as their primary goal. It has been assumed that when gifted undergraduate students with their high intelligence set meaningful main goals, it was made with careful consideration, and the goals have gone through a rigorous selection process. Thus, it is not easy or possible to make a new one with the same meaning and importance.

"... I also want to set new goals. Then I think, if you can't (reach my previous goalred), then just forget about it. But I can't, it's just that it's still in the back of my mind. Oh, my life revolves around this goal, no, it's still on my mind and yes, then if there is an opportunity to get closer to that goal, try to take it "'(M, 18 yo)

\section{Discussion}

This study examined the role of goal adjustment (goal disengagement and goal re-engagement) as a moderator of perfectionism and academic achievement in Indonesian gifted undergraduate students. The different moderation effects between goal disengagement and goal reengagement were found. Goal reengagement does not significantly predict academic achievement and, therefore, not significant as a moderator in the relationship between perfectionism and academic achievement. Meanwhile, goal disengagement shows a different result as a significant moderator in the relationship between perfectionism and academic achievement.

A possible explanation for the differential effects of goal disengagement and goal re-engagement is related to adaptive and maladaptive perfectionism (Eddington, 2014). A previous study suggests that goal re-engagement interacts with adaptive perfectionism in context with adaptive coping (Eddington, 2014). The result of this study shows consistency, but in a different context that is academic achievement, the goal re-engagement might not be suitable to explain maladaptive perfectionism.

The finding in this study is not in line with the concept of interaction between goal disengagement and re-engagement in Mens et al. (2016) and Messay \& Marsland's (2015) works. It is said that goal re-engagement has a more prominent role in achieving one particular goal successfully, students who have a goal reengagement seem more able to survive in facing obstacles in completing their assignments. Based on the qualitative results obtained, gifted undergraduate students from both groups said they found it challenging to make a new meaningful goal. Gifted undergraduate students were known as students with high-level intelligence (Davis et al., 2014; Worrell et al., 2019) and high metacognition ability (Steiner, 2006). Therefore, when they set a goal, this goal is based on deep thought and complex considerations. If they have to make a new goal due to circumstance, they have difficulty in doing so. It has also been assumed that gifted undergraduate students believe that their goal or their high academic standard defines their achievement and what is expected from them by their parents or important persons around them (Kerr, 2009; Speirs Neumeister et al., 2009). Therefore, goal re-engagement is perhaps something that this gifted undergraduate students would 
not take as an option. When they make a new goal, the goal will not as meaningful as their first main goal. Actually, this goal is an intermediary goal to achieve the main meaningful goal that has been set at the beginning.

A previous finding that goal disengagement with the right level of perfectionism would lead to adaptive coping (Eddington, 2014). By the findings in this study, goal disengagement was found to moderate the relationship between maladaptive perfectionism and academic achievement significantly. Gifted undergraduate students with high goal disengagement can make adjustments to their meaningful goals. From interviews analysis, it was known when gifted undergraduate students with low levels of perfectionism - high GPA is facing failure or obstacles to achieving their meaningful goal, and they are better able to temporarily release the goal than gifted undergraduate students with a high level of perfectionism - low GPA. The goal disengagement process undertaken by gifted undergraduate students is that they temporarily break away from the meaningful goal, to intermediary goals that will bring them closer to their main meaningful goal.

The different findings of goal disengagement and goal re-engagement among gifted undergraduate students also can be explained by their unique characteristics. Our qualitative result revealed in gifted undergraduate students have high intellectual abilities, and they have confidence in themselves to achieve any high goals. The thought of attaching to another goal (goal re-engagement) is not in line with the high personal standards that gifted undergraduate students develop themselves. Meanwhile, for the time being, moving (goal disengagement) to a temporary intermediary goal and then returning to try to achieve the main meaningful goal is still acceptable for them.

An interesting finding related to the goal adjustment and peculiarities of gifted undergraduate students in Indonesia. It was found in this study that in the process of making a meaningful goal, they have considered many aspects. However, they have not considered all of the external factors. With Indonesia's pluralist culture, gifted undergraduate students must adapt to their study group members' abilities. The constraints in this study group, among others, is one of the reasons for gifted undergraduate student need to make goal adjustments.

Another finding in this study is that studies found that maladaptive perfectionism is negatively correlated with academic achievement (Grzegorek et al., 2004; Madigan, 2019; Rice \& Slaney, 2002). It is suggested that the higher their maladaptive perfectionism, the lower their academic achievement.

The maladaptive perfectionists' high personal standards are accompanied by their negative thoughts that they will be failing and making mistakes. This naturally leads the maladaptive perfectionists to struggle in focusing their efforts and mind on achieving their high standard academic achievement goals. From qualitative data, this accordance with the fact that gifted undergraduate students see maladaptive perfectionism will negatively affect their GPA score. Gifted undergraduate students with a high level of maladaptive perfectionism - low GPA said these high standards lead them to behave in a counterproductive manner, for example focusing more on the process of making and preparing tasks rather than completing, difficulty sleeping or thinking negatively about their academic assignments and tasks. It is not infrequently the counterproductive behavior makes it difficult for them to perform well in class.

The present study was limited to examine the influence of perfectionism on academic achievement with goal adjustment as a moderator in the collegiate setting, this limited the results to a college student as a group. Academic achievement, 
exclusively identified by GPA, is another possible limitation. Students who took part in this study are gifted undergraduate students. Therefore, they tend to have a high score for their GPA and minimize the variability of academic achievement.

\section{Conclusion}

Based on the sequential explanatory model research that has been done, it can be concluded that goal disengagement moderates the relationship between maladaptive perfectionism and academic achievement, while goal re-engagement does not significantly moderate the relationship between maladaptive perfectionism and academic achievement. An explanation of the unique dynamics of intellectually gifted students on variables is obtained from the conclusion of the second stage of qualitative research. It could be concluded that it is difficult for gifted undergraduate students to make adjustments to their academic goals. Those who can do goal disengagement will be more flexible in facing failure, and in the end, achieving their meaningful academic goals.

The results obtained have implications for psychologists and tertiary institutions who need to know the tendency of maladaptive perfectionism in gifted students with low academic achievement and conduct counseling to overcome it. Students who also have awareness of the tendency of maladaptive perfectionism and their impact on academic achievement could develop goal disengagement to their unattainable goals.

It would be of value for future research not to limit the population to college-aged students alone. The generalization in this study only applies to students age 17-22 years old, further study with a student from a different age group could become a comparison for broader generalizations. Another possibility for further research, the researcher could consider using another method to identify gifted undergraduate student's academic achievement. This study used the GPA to represent the academic achievement of gifted undergraduate students. The GPA shortrange and score grouping in high score potential to minimize the variability of academic achievement. By using GPA, it is quite difficult to include gifted undergraduate students with low academic achievement without a specific independent process.

\section{References}

Akbar-Hawadi, R. (2004). Akselerasi A-Z informasi program percepatan belajar dan anak berbakat intelektual ( $\mathrm{R}$. Akbar-Hawadi, ed.). PT Grasindo.

Ananda, N. Y., \& Mastuti, E. (2013). Pengaruh perfeksionisme terhadap prokrastinasi akademik pada siswa program akselerasi. Jurnal Psikologi Pendidikan dan Perkembangan, 2(3), 226-231.

Blaas, S. (2014). The relationship between social-emotional difficulties and underachievement of gifted students. Australian Journal of Guidance and Counselling, 2431(10), 243-255. https://doi.org/10.1017/jgc.2014.1

Blankstein, K. R., Dunkley, D. M., \& Wilson, J. (2008). Evaluative concerns and personal standards perfectionism: Self-esteem as a mediator and moderator of relations with personal and academic needs and estimated GPA. Current Psychology, 27, 29-61. https://doi.org/10.1007/s12144-0089022-1

Brown, E. J., \& Heimberg, R. G. (1999). Relationship of perfectionism to affect, expectations, attributions and performance in the classroom. Journal of Social \& Clinical Psychology, 18(1), 98-120.

https://doi.org/https://doi.org/10.1521/j scp.1999.18.1.98

Brumbaugh, J., Lepsik, R., \& Olinger, C. (2007). The relationship between GPA and perfectionism. Undergraduate 
Research Journal for the Human Sciences, 6.

Callard-Szulgit, R. (2012). Perfectionism and gifted children. Rowman \& Littefield Education.

Chan, D. W. (2010). Healthy and unhealthy perfectionists among academically gifted chinese students in Hong Kong: Do different classification schemes make a difference? Roeper Review, $32(2)$, 88-97. https://doi.org/10.1080/027831910035 87876

Creswell, J. W. (2007). Qualitative inquiry and research design: Choosing among five approaches (2nd ed.). SAGE Publication Inc.

Creswell, J. W. (2016). Research design: Pendekatan metode kualitatif, kuantitatif dan campuran (Edisi keenam). Penerbit Pustaka Pelajar.

Creswell, J. W., \& Creswell, J. D. (2018). Research design: Qualitative, quantitative, and mixed methods approaches (Fifth ed). SAGE Publications, Inc.

Davis, G. A., Rimm, S., \& Siegle, D. (2014). Education of the gifted and talented (sixth ed). Pearson New International Edition.

Drenth, P. J. D., Bleichrodt, N., Dengah, B., Soemarto, \& Poespadibrata, S. (1976). Buku pegangan test intellegensi kolektip Indonesia (TIKITinggi). Fakultet Psychologi Vrije Universiteit Amsterdam dan Universitas Padjadjaran.

Eddington, K. M. (2014). Perfectionism, goal adjustment, and self-regulation: A short-term follow-up study of distress and coping. Self and Identity, 13(2), 197-213.

https://doi.org/10.1080/15298868.2013 .781740

Elion, A. A., Wang, K. T., Slaney, R. B., \& French, B. H. (2012). Perfectionism in African American students: Relationship to racial identity, GPA, self-esteem, and depression. Cultural
Diversity and Ethnic Minority Psychology, 18(2), 118-127. https://doi.org/10.1037/a0026491

Field, A. P. (2009). Discovering statistics using IBM SPSS statistics (Third edition). SAGE Publication Ltd.

Fong, R. W., \& Yuen, M. (2014). Perfectionism and chinese gifted learners. Roeper Review, 36(2), 81-91. https://doi.org/10.1080/02783193.2014 .884202

Frost, R. O., Lahart, C. M., \& Rosenblate, R. (1991). The development of perfectionism: A study of daughters and their parents. Cognitive Therapy and Research, 15(6), 469-489. https://doi.org/10.1007/BF01175730

Grzegorek, J. L., Slaney, R. B., Franze, S., \& Rice, K. G. (2004). Self-criticism, dependency, self-esteem, and grade point average satisfaction among clusters of perfectionists and nonperfectionists. Journal of Counseling Psychology, 51(2), 192$200 . \quad$ https://doi.org/10.1037/00220167.51.2.192

Hayes, A. F. (2018). Introduction to mediation, moderation, and conditional process analysis second edition: A regression-based approach (second ed). The Guilford Press.

Hébert, T. P., \& Smith, K. J. (2018). Social and emotional development of gifted students. Gifted Child Today, 41(4), 176.

https://doi.org/10.1177/107621751878 8591

Kakavand, A., Kalantari, S., Noohi, S., \& Taran, H. (2017). Identifying the relationship of parenting styles and parent's perfectionism with normal students' and gifted students' perfectionism. Independent Journal of Management \& Production, 8(1), 108123.

https://doi.org/10.14807/ijmp.v8i1.501

Kemendikbud. (2020). Peraturan Menteri Pendidikan dan Kebudayaan Republik Indonesia Nomor 3 Tahun 2020. 
https://lldikti13.kemdikbud.go.id/wpcontent/uploads/2020/01/Permendikbu d-Nomor-3-Tahun-2020.pdf

Kerr, B. (2009). Encyclopedia of giftedness, creativity, and talent. SAGE Publications.

Lee, D. -g., \& Park, H. -j. (2011). Crosscultural validity of the frost multidimensional perfectionism scale in Korea. The Counseling Psychologist, 39(2), 320-345. https://doi.org/10.1177/001100001036 5910

Lubis, F. Y., Hawadi, L. F., Salim, R. M. A., \& Purwono, U. (2020). Perfeksioniame maladaptif dan prestasi akademik pada mahasiswa berbakat intelektual: Suatu pendekatan riset campuran sekuensial. Journal of Psychological Science and Profession, 4(1), 56. https://doi.org/10.24198/jpsp.v4i1.269 62

Madigan, D. J. (2019). A meta-analysis of perfectionism and academic achievement. Educational Psychology Review, 31(4), 967-989. https://doi.org/10.1007/s10648-01909484-2

Mens, M. G., Scheier, M. F., \& Wrosch, C. (2016). Goal adjustment theory. In S. K. Whitbourne (Ed.), The encyclopedia of adulthood and aging (First, pp. 15). John Wiley \& Sons, Inc. https://doi.org/10.1002/978111852892 1.wbeaa0192

Messay, B., \& Marsland, A. L. (2015). Goal adjustment ability predicts magnitude of emotional and physiological responses to an unsolvable anagram task. Personality and Individual Differences, 86, 417421.

https://doi.org/10.1016/j.paid.2015.07. 010

Miller, a. L., Lambert, a. D., \& Speirs Neumeister, K. L. (2012). Parenting style, perfectionism, and creativity in high-ability and high-achieving young adults. Journal for the Education of the Gifted, 35(4), 344-365. https://doi.org/10.1177/016235321245 9257

Mofield, E. L., \& Peters, M. P. (2015). The relationship between perfectionism and overexcitabilities in gifted adolescents. Journal for the Education of the Gifted, 38(4), 405-427. https://doi.org/10.1177/016235321560 7324

Moreno, R. (2010). Educational psychology. John Wiley \& Sons.

Munandar. (2011). Buku petunjuk penggunaan tes kreativitas verbal. LPSP3 UI.

Neihart, M., Reis, S. M., Robinson, N. M., \& Moon, S. M. (2002). The social and emotional development of gifted children. what do we know?. Prufrock Press, Inc.

Nurhayati, Akbar, S. N., \& Mayangsari, M. D. (2014). Hubungan perfeksionisme dengan kesejahteraan psikologis pada siswa akselerasi. Jurnal Ecopsy, 1(4). https://doi.org/http://dx.doi.org/10.205 27/ecopsy.v1i4.508

O'Connor, R. C., \& Forgan, G. (2007). Suicidal thinking and perfectionism: The role of goal adjustment and behavioral inhibition/activation systems (BIS/BAS). Journal of Rational - Emotive and Cognitive Behavior Therapy, 25(4), 321-341. https://doi.org/10.1007/s10942-0070057-2

Orange, C. (1997). Gifted students and perfectionism. Roeper Review, 20(1), 39-41. https://doi.org/10.1080/027831997095 53849

Parker, W. D. (2000). Healthy perfectionism in the gifted. Journal of Secondary Gifted Education, 11(4), 173-182. https://doi.org/10.4219/jsge2000-632

Peterson, J., Duncan, N., \& Canady, K. (2009). A longitudinal study of negative life events, stress, and school 
experiences of gifted youth. Gifted Child Quarterly, 53(1), 34-49. https://doi.org/10.1177/001698620832 6553

Renzulli, J. S., \& Reis, S. M. (1985). The schoolwide enrichment model: A comprehensive plan for educational excellence. Creative Learning Press.

Rice, K. G., \& Dellwo, J. P. (2002). Perfectionism and self-development: Implications for college adjustment. Journal of Counseling \& Development, 80 , 188-196. https://doi.org/10.1002/j.15566678.2002.tb00182.x

Rice, K. G., \& Slaney, R. B. (2002). Clusters of perfectionists: Two studies of emotional adjustment and academic achievement. Measurement and Evaluation in Counseling and Development, 35(1), 35-48.

Rimm, S. (2006). When gifted students underachieve what you can do about it. Prufrock Press, Inc.

Rosadi, N., \& Widayat, I. W. (2012). Hubungan antara perfeksionisme dengan depresi pada siswa cerdas istimewa di kelas akselerasi. Jurnal Psikologi Pendidikan dan Perkembangan, 1(2), 100-106.

Sastre-Riba, S., Fonseca-Pedrero, E., \& Ortuño-Sierra, J. (2019). From high intellectual ability to genius: Profiles of perfectionism. Comunicar, 27(60), 9-17. https://doi.org/10.3916/C602019-01

Siaran Pers Kemenristekdikti. (2017). 100 besar perguruan tinggi non politeknik dan 25 besar perguruan tinggi politeknik di Indonesia tahun 2017. https://www.ristekbrin.go.id/100besar-perguruan-tinggi-non-politeknikdan-25-besar-perguruan-tinggipoliteknik-di-indonesia-tahun-2017/

Silverman, L. K. (1999). Perfectionism: The crucible of giftedness. Gifted Education International, 23(3), 233245.

https://doi.org/10.1177/026142940702
300304

Sousa, D. A. (2009). How the gifted brain learns (2nd ed). Corwin Press, Inc.

Speirs Neumeister, K. L. (2004a). Factors influencing the development of perfectionism in gifted college students. Gifted Child Quarterly, 48(4), 259-274. https://doi.org/10.1177/001698620404 800402

Speirs Neumeister, K. L. (2004b). Understanding the relationship between perfectionism and achievement motivation in gifted college students. Gifted Child Quarterly, 48(3), 219-231. https://doi.org/10.1177/001698620404 800306

Speirs Neumeister, K. L., \& Finch, H. (2006). Perfectionism and achievement motivation in high-ability students. Journal for the Education of the Gifted, 50(3), 238-251. https://doi.org/10.1177/016235321559 2502

Speirs Neumeister, K. L., Williams, K. K., \& Cross, T. L. (2009). Gifted highschool students' perspectives on the development of perfectionism. Roeper Review, 31(4), 198-206. https://doi.org/10.1080/027831909031 77564

Steiner, H. H. (2006). A microgenetic analysis of strategic variability in gifted and average-ability children. Gifted Child Quarterly, 50(1), 62-74. https://doi.org/10.1177/001698620605 000107

Steiner, H. H., \& Carr, M. (2003). Cognitive development in gifted children: Toward a more precise understanding of emerging differences in intelligence. Educational Psychology Review, 15(3), 215-246. https://doi.org/https://doi.org/10.1023/ A:1024636317011

Stoeber, J. (2018). The psychology of perfectionism: Theory, research, applications. Routledge. 
Stornelli, D., Flett, G. L., \& Hewitt, P. L. (2009). Perfectionism, achievement, and affect in children: A comparison of students from gifted, arts, and regular programs. Canadian Journal of School Psychology, 24(4), 267-283. https://doi.org/10.1177/082957350934 2392

VanTassel-Baska, J. L., Cross, T. L., \& Olenchak, F. R. (2009). Socialemotional curriculum with gifted and talented students. Prufrock Press, Inc.

Wang, K. T., Fu, C.-C., \& Rice, K. G. (2012). Perfectionism in gifted students: Moderating effects of goal orientation and contingent self-worth. School Psychology Quarterly: The Official Journal of the Division of School Psychology, American Psychological Association, 27(2), 96108. https://doi.org/10.1037/a0029215
Worrell, F. C., Subotnik, R. F., OlszewskiKubilius, P., \& Dixson, D. D. (2019). Gifted students. Annual Review of Psychology, 70(1), 551-576. https://doi.org/10.1146/annurev-psych010418-102846

Wrosch, C., Scheier, M. F., Miller, G. E., Schulz, R., \& Carver, C. S. (2003). Adaptive self-regulation of unattainable goals: Goal disengagement, goal re-engagement, and subjective well-being. Personality and Social Psychology Bulletin, 29(12), 1494-1508. https://doi.org/10.1177/014616720325 6921 
Psympathic, Jurnal Ilmiah Psikologi Desember 2020, Vol. 7, No. 2, Hal. : 169-184 